\title{
Control of a stand-alone photovoltaic/battery bank system to supply energy to resistance load
}

\author{
G. Giftson Samuel ${ }^{1}$, M. Muthuramalingam ${ }^{2}$, P. S. Manoharan ${ }^{3}$, C. Christober Asir Rajan ${ }^{4}$ \\ ${ }^{1}$ Department Electrical and Electronics Engineering, Sir Issac Newton College of Engineering and Technology, India \\ ${ }^{2}$ Department Electrical and Electronics Engineering, Suguna College of Engineering, India \\ ${ }^{3}$ Department of Electrical and Electronics Engineering, Thiagarajar College of Engineering, India \\ ${ }^{4}$ Department of Electrical and Electronics Engineering, Pondicherry Engineering College, India
}

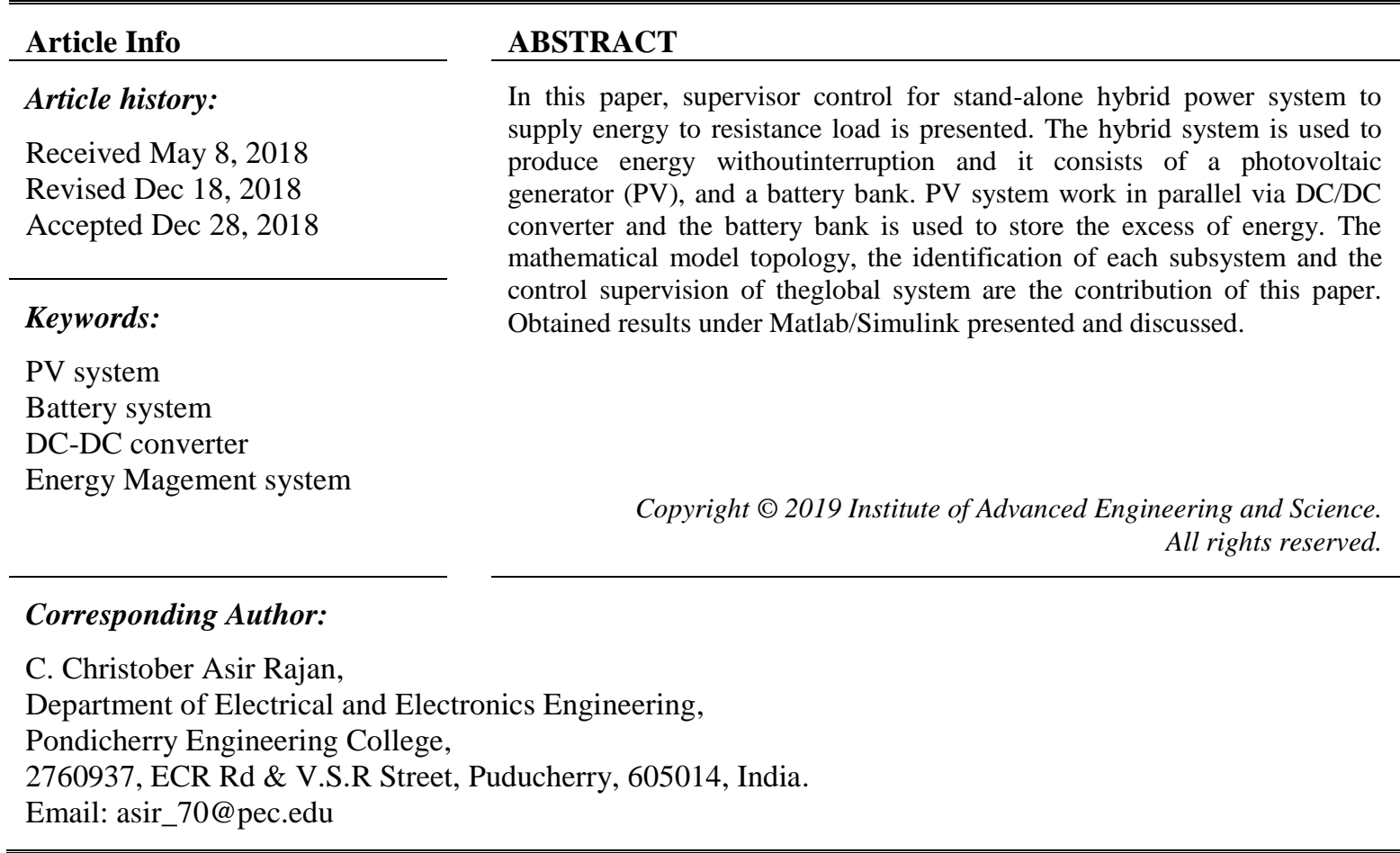

\section{INTRODUCTION}

A prior objective is to improve the sustainable energy development by implementing strategic technology over exhaustible fossil based fuel replaced by renewable energy resources. Among them nowadays photovoltaic energy has an increased importance in all over electrical power applications, since it is considered as an abundantly available renewable energy resource and it is inexhaustible in nature [1]. The photovoltaic processes are completely solid state and self contained. It has no moving parts and has no materials consumed or emitted [2]. Additionally, they generate power near the load centers, which eliminates the need to run high-voltage transmission lines through urban and rural areas [3]. Due to the erratic nature of solar energy, stand-alone PV system usually needs other generation sources or energy storage devices to form a hybrid systemThe storage device can be superconducting magnetic energy storage (SMES), battery bank, FC electrolyzer system or a super capacitor bank [4-12]. An important characteristic of solar panels is that the available maximum power is provided only in a single operating point given by a localized voltage and current known, called Maximum Power Point (MPP). Another problem is that the position of this point is not fixed but it moves according to the irradiance, the temperature and load. Because of the relatively expensive cost of this kind of energy we must extract the maximum of watts of solar panels. This requires a mechanism for the pursuit (tracking) of the MPP called maximum power point tracking (MPPT) so that maximum power is generated permanently. Artificial intelligent technology may be added to improve the maximum power tracking capability of solar panel [13-14]. 
In standalone PV applications, electrical power is required from the system during night or hours of darkness. Thus the storage must be added to the system. Generally, batteries are used for energy storage. Several types of batteries can be used such as lead-acid, nickel-cadmium, lithium zinc bromide, zinc chloride, sodium sulfur, nickel-hydrogen, redox and vanadium batteries . A charge controller must keep the battery at the highest possible state while protecting it from overloaded by the photovoltaic generator and from over-discharge by loads [15]. There are several types of charge controller. We prefer MPPT tracking controller for its importance over other controller for better utilization of power from the solar array. Here we use SEPIC controller for better utilization of power from the sun and improve the state of charging in the storage devices. Different types of load can be operated by using the standalone solar power [16-18]. Here we are using resistance load. We depict the results through MATLAB/Simulink software.

The paper is organized as follows. In Section 2, we present the Modeling of photovoltaic panels. Then, Simple linear battery model approach is reported in Section 3. After, we developed Supervisor control of the studied system in Section 4. Section 5 shows the simulation results of Supervisor control of standalone PV system. Section 6 contains a conclusion of this study.

\section{STUDIED SYSTEM MODELING}

\subsection{Modeling of photovoltaic panels}

An ideal solar cell can be modeled as a current source parallel connected across a diode. Solar PV cell is usually represented by equivalent circuit, which is composed of current source parallel to the diode. It is called an ideal model as shown in Figure 1. Adding series resistance $R_{s}$ and shunt resistance $R_{s h}$ to the ideal model is called single diode model or five parameter model. Because of its accuracy, it is frequently used by many researchers. Some researchers consider that the parallel resistance is very high value close to infinity. So, it can be neglected. Hence, the circuit is called four parameter model which comprises of ideal model with RS only Based on the Shockley and Queisser (SQ) diode equation, the mathematical equation, that describes the I-V relationship of ideal PV cell from the Figure 1.

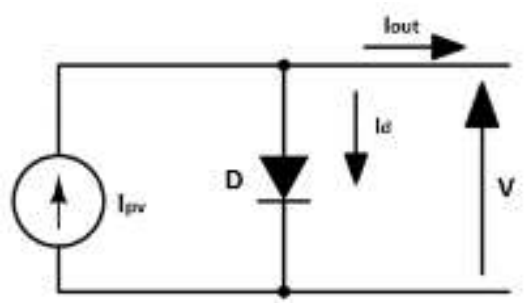

Figure 1 Ideal model

In this work, A solar cell usually represented by equivalent circuit,which is composed of current source parallel to the diode, which is called ideal model as shown in Figure 2. Adding series resistance $R_{s}$ and shunt resistance $R_{s h}$ to the ideal model is called single diode model or five parameter model shown in Table 1 is considered for modeling of solar panel.

$I=I_{p h}-I_{d}$

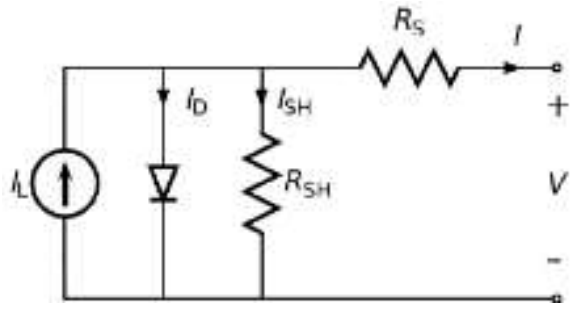

Figure 2, Equivalent circuit of solar cell 


$$
I_{d}=I_{0}\left[\exp \left(\frac{V_{d}}{A V_{T}}\right)-1\right]
$$

Substituting (2) into (1) gives the I-V relationship of the solar PV cell as:

$$
I=I_{p h}-I_{0}\left[\exp \left(\frac{q V}{A K T}\right)-1\right]
$$

Table 1. PV panel parameter

\begin{tabular}{lc}
\hline \multicolumn{1}{c}{ Parameter } & Value \\
\hline Open circuit voltage & $22.2 \mathrm{~V}$ \\
Short circuit current & $10.1 \mathrm{~A}$ \\
Voltage at Pmax & $17.45 \mathrm{~V}$ \\
Current at Pmax & $9.27 \mathrm{~A}$ \\
\hline
\end{tabular}

The current- voltage characteristic equation of a solar cell referred to in Figure 3 is given asphotocurrent depends on the solar insulation and cell's working temperature, is given as-The cell's saturation current changes with the cell temperature. The output characteristics of PV system are non-linear and it changes with Insolation and Temperature. When these two factors vary, MPP point varies accordingly. In Figure 3(a) and (b) P-V and I-V graph is shown. With increase in insolation the MPP voltage increases and thereby the maximum current also increases. For the insulation level above $300 \mathrm{~W} / \mathrm{m}^{2}$ the MPP is almost constant.

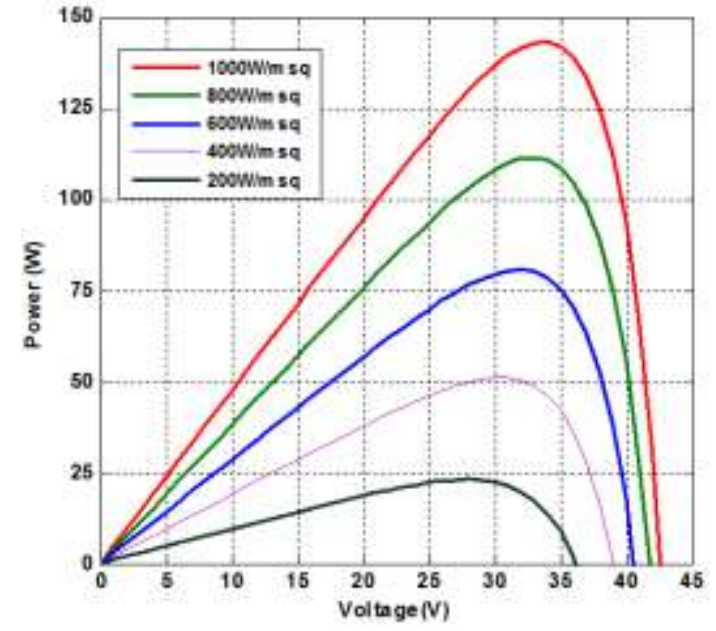

(a)

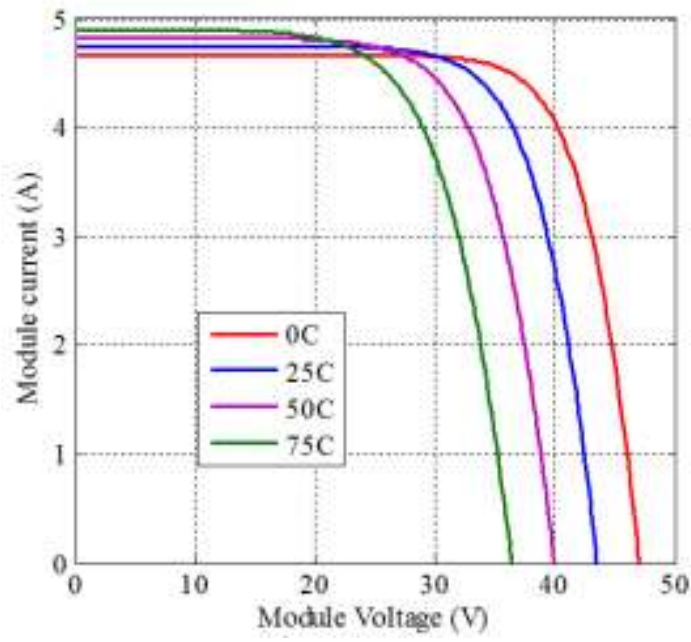

(b)

Figure 3(a). Power vs. Voltage of PV panel (b) Current vs. Voltage of PV panel

\subsection{Simple linear battery model}

This model can be suitable if the state of charge is not considered or the battery is assumed to have unlimited energy. The model does not take into account the effects of varying state of charge and is therefore not suitable if the available voltage at different charge levels is of interest. Even with an extremely simple model like this, the discharge curve can be modeled somewhat accurately in the linear area that can be seen in Figure 3 from around $20 \%$ to around $80 \%$ of discharge. The voltage as a function of discharge level produced by this model is a straight horizontal line that goes up or down based on the amplitude of the discharging current. State of charge dependent resistance model a small modification of the model outlined in 
above section can be made by including a variable resistor that changes value based on the state of charge (SOC).

$$
E=V_{O}-\left(R_{B}+\frac{K}{S O C}\right) I_{\text {BATTARY }}
$$

State of charge dependent resistance model A small modification of the model outlined in above section can be made by including a variable resistor that changes value based on the state of charge (SOC). The equivalent circuit shown in Figure 4 is based on equation 5. Equation (5) is an empirical mathematical model shown in [13]. The model is very simple and can be accurate over a large part of the SOC- range.

Charge is low as can be seen in Figure 4. The rise in voltage when the state of charge approaches one is absent and this model therefore is very inaccurate in that range. This model was implemented in Simulink/Matlab.

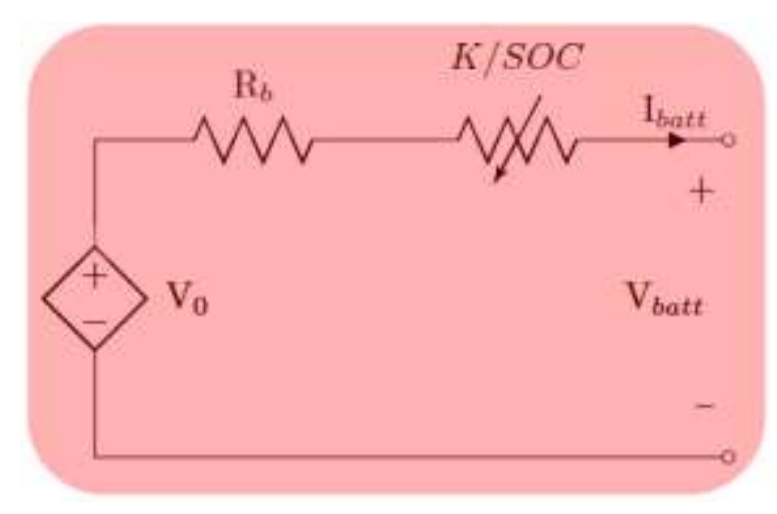

Figure 4. Circuit diagram based on equation 5

Charging and discharging voltage curve as shown in Figure 5 is a function of state of charge resulting from the implementation of the battery model discussed in above section. The curve is not accurate at a high state of charge, but it can be decently accurate at low SOC and in the more at area.
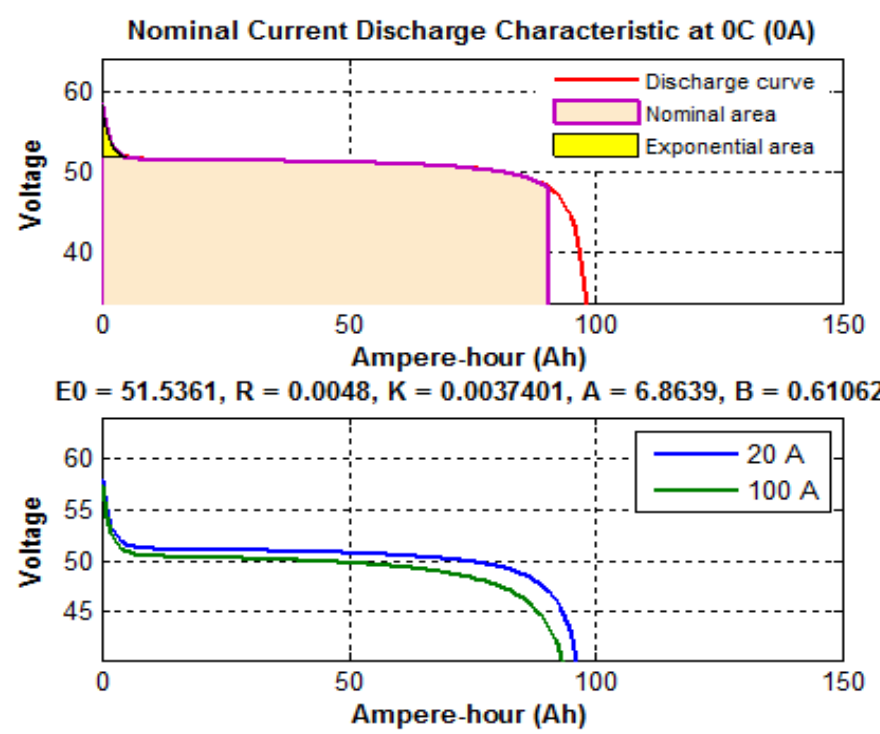

Figure 5. Charging and discharging voltage curve 


\section{SUPERVISOR CONTROL OF THE STUDIED SYSTEM}

The resistance load using battery storage must be recharged regularly. And for those equippedwith PV panels, solar energy is provided only on the presence of sunshine. Generally, EV uses batteries for storage, but due to the less autonomy, Power management control is the model employed in this work consists of a single diode for the cell polarization function and two resistors for the losses. In our work, we choose to use the battery bank system to starts producing energy. The total power is calculated by flowing equation 5

$\mathrm{P}_{\text {load }}=\mathrm{P}_{\text {batt }}+\mathrm{P}_{\mathrm{pv}}$

We can note from the obtained results, that the proposed hybrid system works as proposed by the control supervisor. To test the robustness of DTC, we make a sudden variation of solar insulation from $1000 \mathrm{~W} / \mathrm{m} 2$ to $850 \mathrm{~W} / \mathrm{m} 2$. We obtain the following results. The results obtained confirm the presented theory. We note that even if the dynamic change in load from $0.2 \mathrm{~s}$ to $0.4 \mathrm{~s}$. For a good energy management, control strategy has been established. The supervisor control has been used to coordinate the three sources to supply the load. The simulation of the hybrid system has been developed using MATLAB/Simulink and the obtained results show the feasibility of the hybrid system production for an electric vehicle and it will be interesting to use a modulated hysteresiscontroller to reduce the torque ripples.

\section{SIMULATION RESULT AND DISCUSSION}

The Figure 6 shows the whole set up of our simulation. It comprises PV panel, SEPIC converter, MPPT, controller with boost converter and battery (as the energy storage element).Capacitor Cin is to reduce the ripples in MPP voltage. It should be smaller in magnitude otherwise more time will be consumed to obtain MPP.

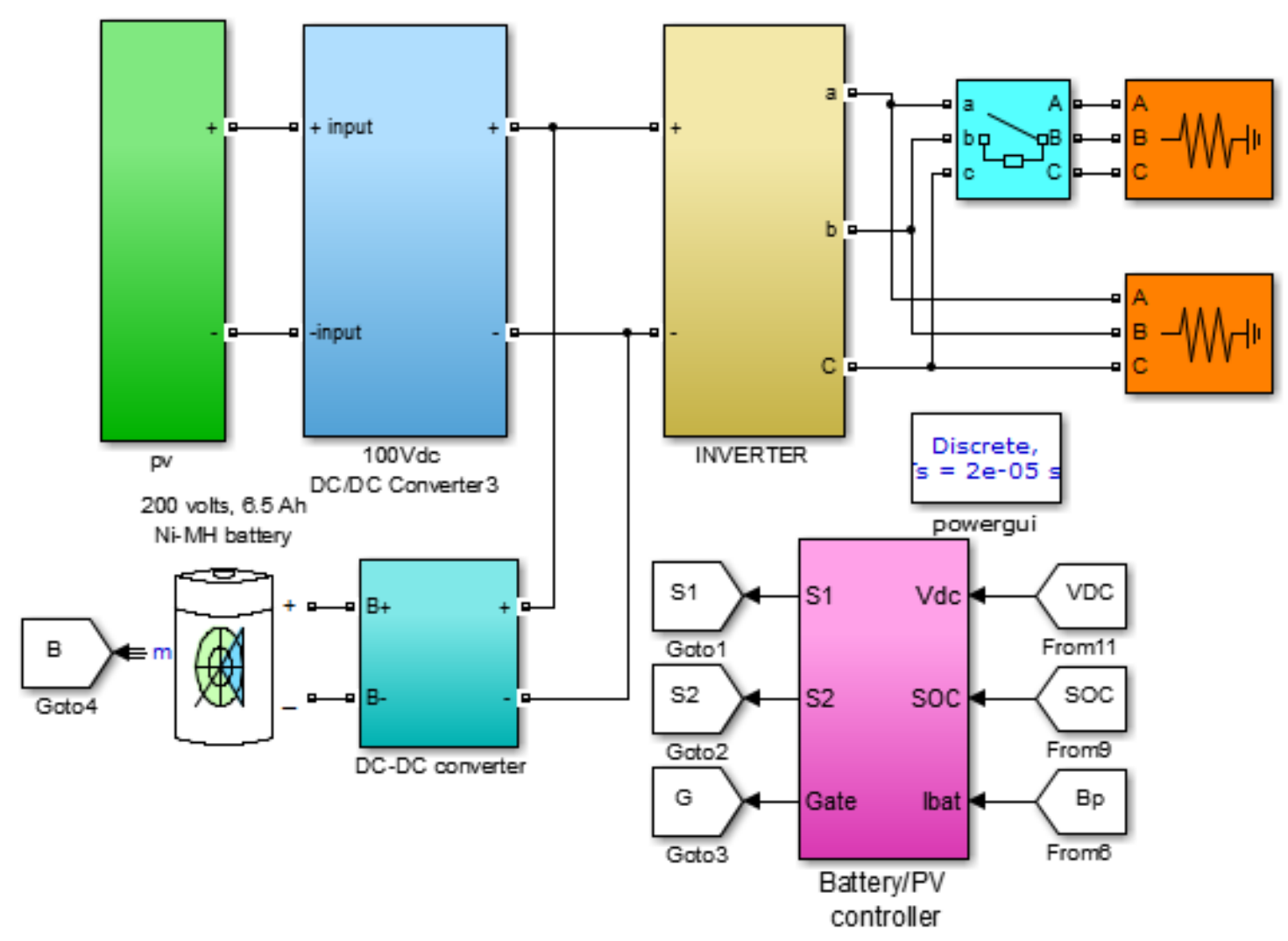

Figure 6. Simulation circuit diagram 
Figure 7 represents output voltage of PV panel after doing a MPP control solar irradiation of 1000 $\mathrm{W} / \mathrm{m} 2$ to $850 \mathrm{~W} / \mathrm{m} 2$ and cell temperature $25^{\circ} \mathrm{C}$. Observed result of output voltage the P\&O MPPT algorithm considerable performance compare to the convention $\mathrm{P} \& \mathrm{O}$ algorithm The voltage current first increases but after reaching the MPP voltage it becomes constant.

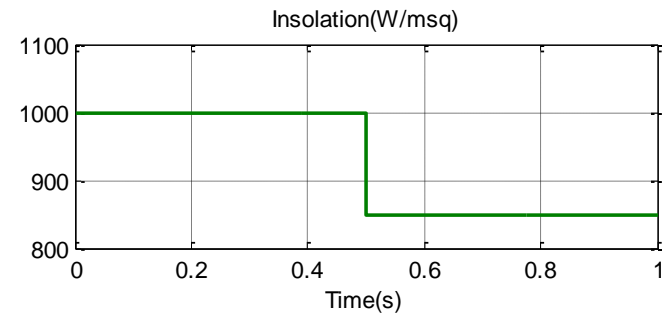

Figure 7. Simulation of PV Insolation

Figure 8 to Figure 11 are DC input voltage and current.AC output voltage and current, rms output power, and combined power PV and Battery system. The $\mathrm{P} \& \mathrm{O}$ algorithm extract maximum power the control algorithm maintained constant voltage even dynamic change in load condition.
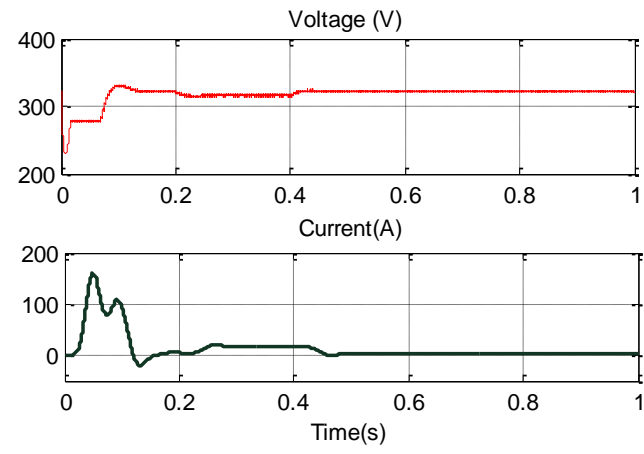

Figure 8. Converter voltage and current
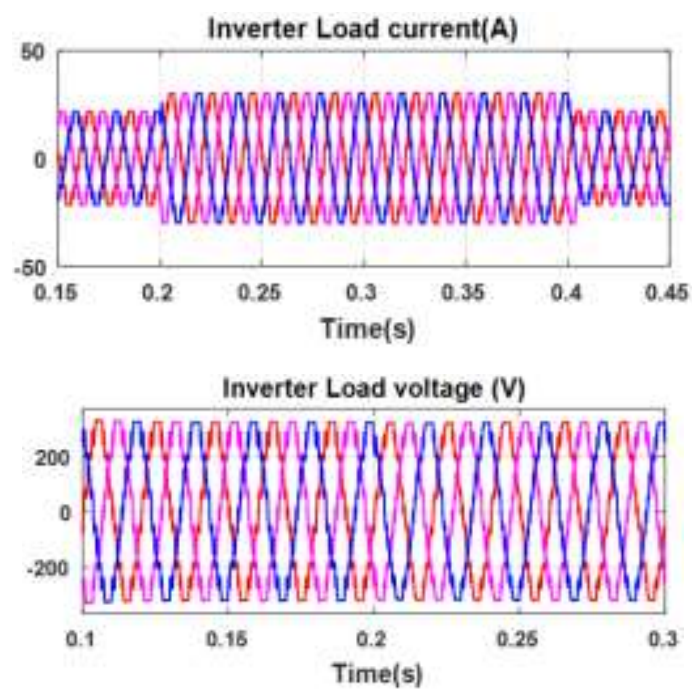

Figure 9. Inverter output voltage and current 

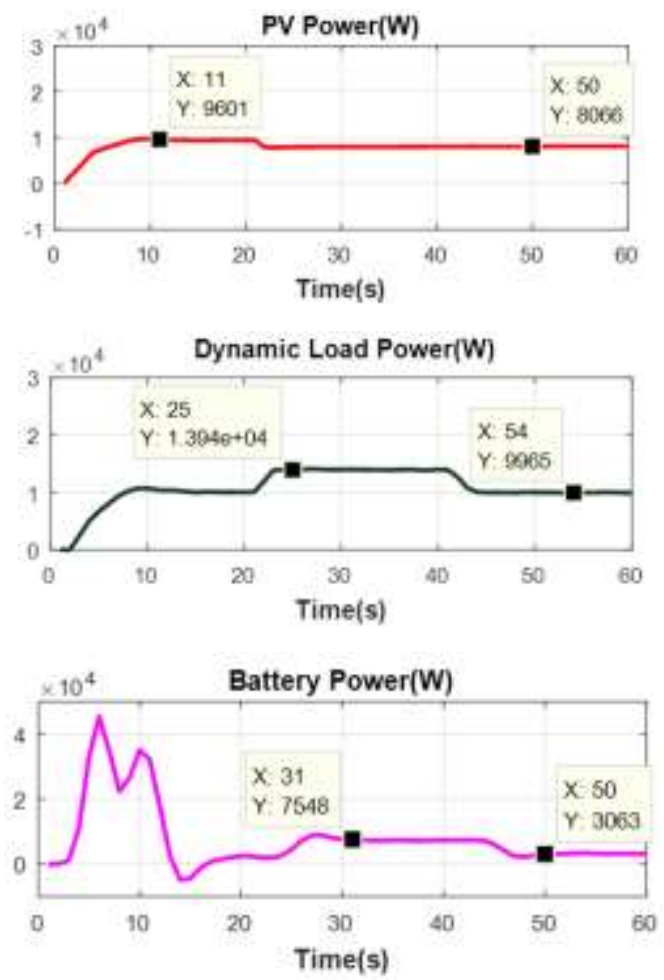

Figure 10. Power RMS Load, Battery and PV

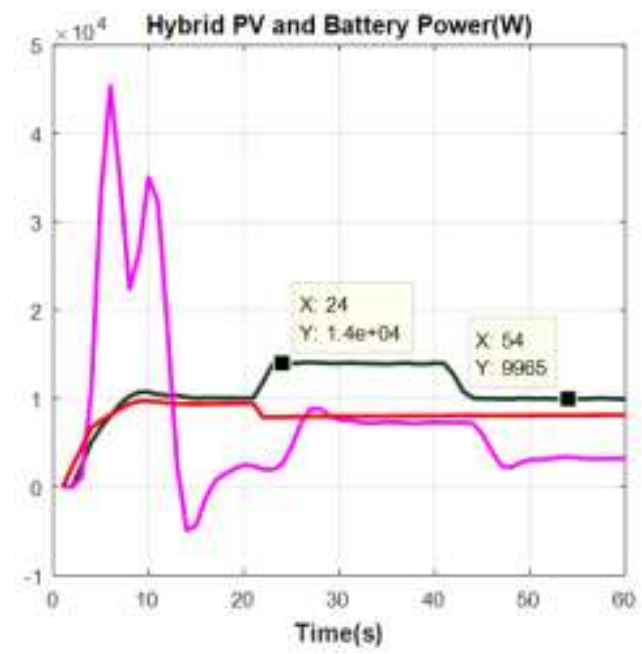

Figure 11. PV battery combined power of system

\section{CONCLUSION}

A Simulink implementation based on the five parameter diode PV model has beenconstructed. The effects of varying model parameter values and the effect of different solar light intensity and ambient temperature have been demonstrated.All the parameters in the PV model can be estimated automatically by the parameter approximation method outlined. This method is implemented in such a waythat it enables easy simulation of different solar modules just by supplying datasheet parameter values to the script. The PV model can be automatically modified to simulate configurations ranging from a single PV cell to a string of modules.Maximum power point tracking using the $\mathrm{P} \& \mathrm{O}$ algorithm has beenimplemented. The maximum power point tracking implementations successfully keepsthe voltage close to the MPP most of the time.Modeling of battery cells is done by curve fitting from manufacturer's dischargecurves. The implemented model utilizes a state of charge dependent controlledvoltage source and an internal resistance. 
As with the PV model, it can be automatically modified to different configurations from a single cell to a module withseveral strings in parallel. The major weaknesses are that there is no modeling ofcurrent dependent capacity and no temperature dependence.A Stand-alone Photovoltaic System for residential applications is modeled with the help of MATLAB/Simulink. Control methods are employed and verified for the optimum working of the dynamic variation model. Simulation results prove that the SEPIC converter successfully tracks the maximum power point (MPP) of the solar panel and battery is charged accordingly so solar charge controller helps not only in obtaining MPP but also in maintaining state of charge of battery. The results MPPT algorithm ensures an optimum and efficient model for reliable and high quality stand-alone PV system.

\section{REFERENCES}

[1] S. Lalouni, D. Rekioua, T. Rekioua, E. Matagne, "Fuzzy logic control of stand-alone photovoltaic system with batterystorage," Journal of Power Sources, vol. 193, no. 2, pp. 899 - 907, September 2009.

[2] K. Rahrah, D. Rekioua, T. Rekioua, S. Bacha, "Photovoltaic pumping system in Bejaia climate with battery storage," International Journal of Hydrogen Energy, vol. 40, no. 39, pp. 13665-13675, October 2015.

[3] J. K. Kaldellis, K. A. Kavadias, P. S. Koronakis, "Comparing windand photovoltaic stand-alone power systems used for the electrification of remote consumers," Renewable and Sustainable Energy Reviews, vol. 11, no. 1, pp, 57-77, January 2007.

[4] O. C. Onar, M. Uzunoglu, M. S. Alam, "Dynamic modeling, design and simulation of a wind/fuel cell/ultracapacitor-based hybrid power generation system," Journal of Power Sources, vol. 161, no. 1, pp. 707-722, October 2007.

[5] Dimitris Ipsakis, Spyros Voutetakis, Panos Seferlis, Fotis Stergiopoulos, Costas Elmasides, "Power management strategies for a stand-alonepower system using renewable energy sources and hydrogenstorage," International Journal of Hydrogen Energy, vol. 34, no. 16, pp. 7081-7095, August 2009.

[6] Cherry Lodha, Ved Shukla, "Power Management of a stand-alone photovoltaic/fuel cell hybrid energy system," International Journal of Scientific Research Engineering \& Technology, vol. 5, no. 4, pp. 222-226, April 2016.

[7] N. Mebarki, T. Rekioua, Z. Mokrani, D. Rekioua, S. Bacha, "PEM fuel cell/ battery storage system supplying electric vehicle," International Journal of Hydrogen Energy, vol. 41, no. 45, pp. 20993-21005, 7 December 2016.

[8] Caisheng Wang and Hashem Nehrir, "Power management of a stand-alone wind/photovoltaic/fuel-cell energy system," 2008 IEEE Power and Energy Society General Meeting - Conversion and Delivery of Electrical Energy in the 21st Century, Pittsburgh, PA, 2008, pp. 1-1.

[9] Keliang Zhou, J. A. Ferreira, S. W. H. de Haan, Optimal energy management strategy and system sizing method for stand-alone photovoltaic-hydrogen systems, International Journal of Hydrogen Energy, vol. 33, no. 2, pp. 477-489, January 2008.

[10] Sousso Kelouwani, Kodjo Agbossou, Yves Dubé, Loïc Boulon, "Fuel cell Plug-in Hybrid Electric Vehicle anticipatory and real-time blended-mode energy management for battery life preservation," Journal of Power Sources, vol. 221, pp. 406-418, January 2013.

[11] Phatiphat Thounthong, Viboon Chunkag, Panarit Sethakul, Suwat Sikkabut, Serge Pierfederici, Bernard Davat, "Energy management of fuel cell/solar cell/supercapacitor hybrid power source," Journal of Power Sources, vol. 196, no. 1, pp. 313-324, January 2011.

[12] Djamila Rekioua, Samia Bensmail, Nabila Bettar, "Development of hybrid photovoltaic-fuel cell system for standalone application," International Journal of Hydrogen Energy, vol. 39, no. 3, pp. 1604-1611, 16 January 2014.

[13] F. Chekired, C. Larbes, D. Rekioua, F. Haddad, "Implementation of a MPPT fuzzy controller for photovoltaic systems on FPGA circuit," Energy Procedia, vol. 6, pp. 541-549, 2011.

[14] Samia Bensmail, Djamila Rekioua, Halim Azzi, "Study of hybrid photovoltaic/fuel cell system for stand-alone applications," International Journal of Hydrogen Energy, vol. 40, no. 39, 13820-13826, October 2015.

[15] Pablo García, Juan P. Torreglosa, Luis M. Fernández, Francisco Jurado, "Optimal energy management system for stand-alone wind turbine/photovoltaic/hydrogen/battery hybrid system with supervisory control based on fuzzy logic," International Journal of Hydrogen Energy, vol. 38, no. 33, pp. 14146-14158, 4 November 2013.

[16] D. Rekioua and T. Rekioua, "DSP-controlled direct torque control of induction machines based on modulated hysteresis control," 2009 International Conference on Microelectronics - ICM, Marrakech, 2009, pp. 378-381.

[17] Radia Abdelli, Djamila Rekioua, Toufik Rekioua, Abdelmounaïm Tounzi, "Improved direct torque control of an induction generator used in a wind conversion system connected to the grid," ISA Transactions, vol. 52, no. 4, pp. 525-538, July 2013.

[18] H. Ziane, J. M. Retif and T. Rekioua, "Fixed-switching-frequency DTC control for PM synchronous machine with minimum torque ripples," in Canadian Journal of Electrical and Computer Engineering, vol. 33, no. 3/4, pp. 183189, Summer-Fall 2008. 